\title{
ばら積石炭船倉内の腐食を模擬した希硫酸環境における 造船用鋼の腐食および腐食疲労
}

\author{
正員 小 林 佑 規* 正員田 中義 久* \\ 後 藤 英 信* 正員 松 岡 一 祥*
}

Corrosion and Corrosion Fatigue of a Ship Structural Steel in Dilute Sulfuric Acids Substituted for a Corrosion Environment of a Coal Cargo Hold

\author{
by Yuki Kobayashi, Member Yoshihisa Tanaka, Member \\ Hidenobu Goto Kazuyoshi Matsuoka, Member
}

\begin{abstract}
Summary
An acid corrosive environment of a coal cargo hold was reproduced experimentally by using immersions of coal. Immersion tests, crack growth tests, and corrosion fatigue tests were performed under dilute sulfuric acids on a ship structural steel plate.

A pH decreased with passage of time in an exudation solution from coal, and the end point was $\mathrm{pH} 2$. 5. Corrosion rates were obtained in exudation solution and in dilute sulfuric acids of $\mathrm{pH} 4, \mathrm{pH} 3$ and $\mathrm{pH} 2$. It could be confirmed that the corrosion rate in a dilute sulfuric acid could be substituted for that in the exudation solution from coal.

The conditions of the fatigue crack initiation, $\Delta \mathrm{K}_{\mathrm{CF}}$, were obtained from the observations of corrosion pits by a scanning electron microscope. The $\Delta \mathrm{K}_{\mathrm{CF}}$ was 3.60 and $5.39 \mathrm{MPa} \cdot \mathrm{m}^{1 / 2}$ in $\mathrm{H}_{2} \mathrm{SO}_{4}$ at $\mathrm{pH} 4$ and at $\mathrm{pH} 2$, respectively. The crack growth rates estimated under corrosive dissolutions were $5.63 \times 10^{-10}$ and $1.90 \times 10^{-9} \mathrm{~m} /$ cycle for $\Delta \mathrm{K}_{\mathrm{CF}}$ in above environments. Concerning corrosion fatigue, $\mathrm{S} /$ $\mathrm{N}$ curves, Seq/Nc curves on modified MIL HDBK 5 and $\Delta \mathrm{K} / \mathrm{Nc}$ curves were discussed in comparison with corrosion fatigue in seawater.
\end{abstract}

\section{1. 緒言}

船体の腐食衰耗は，貨物油タンクやバラストタンクの上 甲板裏側, 倉内肋骨などが激しいといわれている1”。倉内 浸水や沈没事故の遭遇例として, 1990 年に生じたばら積 貨物船, 鉱石運搬船および鉱油兼用船がある。この事故要 因は, 高齢化（平均船歯 18 年）による船体構造部材の急 速な腐食衰耗のためであり, 載貨重量 5 万トン以上の石炭 と鉄鉱石を運搬する大型船に多いことから，石炭に含まれ る硫黄分と水が反応して希硫酸が生成され，船体構造の鋼 材を腐食したためであると報告されている2。

このような背景から, 本報告では, ばら積石炭船倉内が

\section{* 船舶技術研究所}

原稿受理 平成 11 年 1 月 11 日

春季講演会において講演 平成 11 年 5 月 12,13 日
酸性腐食環境となる状態を石炭滲出液により再現し，腐食 速度, き裂進展速度および腐食疲労に関する実験的検討を 行った。ばら積石炭船倉の腐食に関しては, 輸入炭からの 滲出液が酸性になることを確認し，その滲出液および希硫 酸環境の腐食速度を求める。腐食疲労に関しては, 希硫酸 環境における腐食ピットから疲労き裂が発生する力学的条 件を求め, 実海洋環境の繰返し速度におけるき裂進展速度 を検討する。また, 希硫酸環境の疲労強度は, 公称応力, 修正 MIL-HDBK-5 法の等価応力および応力拡大係数範 井とき裂発生寿命の関係について, 前報 ${ }^{3)-6)}$ の海水腐食疲 労試験結果と合わせて検討する。

\section{2. 供試材および試験片}

供試材は, $500 \mathrm{MPa}$ 級高張力鋼板 K $32 \mathrm{~A}$ （日本海事協 会規格 KA 32）である。板厚は $10 \mathrm{~mm}$, 板表面はショッ トブラスト $(\mathrm{Sa}-2.5)$ が施されたのち, 無機ジンク・シ

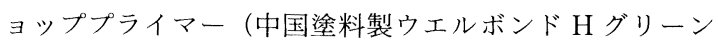


Table 1 Chemical composition of material (mass \%, balance: $\mathrm{Fe}$ )

\begin{tabular}{|c|c|c|c|c|c|c|c|c|c|}
\hline $\mathrm{C}$ & $\mathrm{Si}$ & $\mathrm{Mn}$ & $\mathrm{P}$ & $\mathrm{S}$ & $\mathrm{Cu}$ & $\mathrm{Cr}$ & $\mathrm{Ni}$ & $\mathrm{t} . \mathrm{Al}$ & $\mathrm{Ti}$ \\
\hline 0.14 & 0.20 & 1.14 & 0.016 & 0.01 & 0.03 & 0.029 & 0.02 & 0.02 & 0.02 \\
\hline
\end{tabular}

Table 2 Mechanical properties of material

\begin{tabular}{|c|c|c|c|c|c|c|}
\hline & \multirow{2}{*}{$\begin{array}{c}\text { Elastic } \\
\text { modulus } \\
\mathrm{E} / \mathrm{MPa}\end{array}$} & \multirow{2}{*}{$\begin{array}{l}\text { Upper yield } \\
\text { point } \\
\text { Suy / MPa }\end{array}$} & \multirow{2}{*}{$\begin{array}{c}\text { Lower yield } \\
\text { point } \\
\text { Sly / MPa }\end{array}$} & \multirow{2}{*}{$\begin{array}{l}\text { Ultimate } \\
\text { tensile stress } \\
\mathrm{Su} / \mathrm{MPa}\end{array}$} & \multicolumn{2}{|c|}{ Elongation } \\
\hline & & & & & $\begin{array}{l}\text { at } \mathrm{Su} \\
\delta_{1} / \%\end{array}$ & $\begin{array}{c}\text { at failure } \\
\delta_{2} / \%\end{array}$ \\
\hline (1) & - & 390 & - & 496 & 29 & - \\
\hline (2) & 204,300 & 378 & 364 & 473 & 27 & 35 \\
\hline
\end{tabular}

(1)Mill sheet(JIS Z 2201, Al, $\mathrm{t}=10 \mathrm{~mm}, \mathrm{~W}=40 \mathrm{~mm}, \mathrm{GL}=200 \mathrm{~mm}$ )

(2)Plate specimen $(t=10 \mathrm{~mm}, \mathrm{~W}=40 \mathrm{~mm}, \mathrm{GL}=100 \mathrm{~mm})$

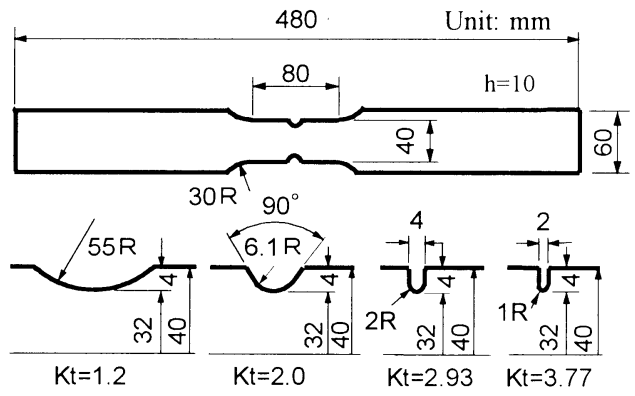

Fig. 1 Shapes and dimensions of notched specimen

I）が $15 \mu \mathrm{m}$ 厚に塗布されている。ミルシートの化学成分

を Table 1 に，機械的性質を Table 2 に示す。

試験片は, 腐食試験片, 切欠き疲労試験片およびき裂進 展試験片に大別される。

腐食試験片は, 大きさ $20 \times 30 \mathrm{~mm}$ の研磨材, ショット ブラスト材およびプライマー材とした。研磨材の板厚は, 板表裏のショットブラスト面をそれぞれ $1 \mathrm{~mm}$ 機械切削 し, $8 \mathrm{~mm}$ とした。ショットブラスト材は，10\%のくえん 酸二アンモニウム水溶液によりプライマーを除去した。シ ヨットブラスト材およびプライマー材の切削側面は研磨さ れている。研磨面の表面仕上げは，いずれの試験片も機械 研磨の後, エメリー紙 1200 \#による手仕上げである。

切久き疲労試験片およびき裂進展試験片は, 供試鋼板か らロール方向を荷重方向に一致させ，鋸盤により採取し た。疲労試験片の切欠きは, 平行部中央の両側に機械加工 し, その形状抢よび寸法を Fig. 1 に示す。応力集中係数 $K_{t}$ は，1.2，2.0，2.93 および 3.77 である。切欠き加工: 部の表面は，エメリーペーパー 400 \#以上の仕上げとした。 き裂進展試験片は, 板幅 $80 \mathrm{~mm}$, 長さ $500 \mathrm{~mm}$ の中央板
厚貫通切久き帯板試験片（CCT）とした。

\section{3. 試 験 方 法}

試験は, 連続および間欠浸漬試験, き裂進展試験および 腐食疲労試験に大別される。

浸漬試験は, 試験片を腐食タンクに約 60 度傾斜して配 列し, 試験液を準静的に循環させ自然腐食状態で行った。 試験液には, 希硫酸水溶液 $\mathrm{pH} 4, \mathrm{pH} 3, \mathrm{pH} 2$ おょよ゙石 炭滲出液を用いた。試験液は, 予め試験環境を保持するリ ザーブタンク（試験液容量 $0.085 \mathrm{~m}^{3}$ ) から, 試験片を配 置した腐食タンク（試験液容量 $0.025 \mathrm{~m}^{3}$ ) ヘポンプ循環 し，1時間に2 回交換されるようにした。リザーブタンク では, 腐食タンクの試験液が, 液温 $25 \pm 1 \mathrm{C}$, 所定の $\mathrm{pH}$ を保持するよう制御した。溶存酸素は空気吹き込みによる 空気飽和状態とした。石炭滲出液を用いた間欠浸漬試験 は, 1 日に 1 時間のみ浸漬し, 他の時間は大気中の湿潤状 態を保持している状態とした。

疲労試験には, 荷重容量 $100 \mathrm{kN}, 200 \mathrm{kN}, 300 \mathrm{kN}$ の フルデジタル制御油圧サーボ疲労試験機を用いた。試験条 件は, 正弦波の荷重制御, 応力比 $R=0.1$ の部分片振り引 張疲労である。試験片は, 油圧チャック部で試験機と電気 的絶縁を行い,さらに絶縁性の油圧:チャックホースを使用 するなどして，試験片のみが独立した腐食系を形成するよ うにした。試験片のつかみは油压チャックである。腐食疲 労試験環境は, 希硫酸 $\mathrm{pH} 4$ および $\mathrm{pH} 2$ 環境とし, 繰返 し速度を $0.17 \mathrm{~Hz}$ とした。なお, 希硫酸環境の疲労試験期 間は, $\mathrm{pH} 4$ 環境が 6 ケ月以内, $\mathrm{pH} 2$ 環境が 1 ケ月以内と した。これ以上の式験期間では, 腐食溶解が大きいため, 負荷応力一定の試験条件が満たされなくなる。き裂進展試 験は，希硫酸 pH 4 抢よび pH 3 環境とした。 


\section{4. 試験結果とその検討}

\section{1 ばら積石炭船倉の腐食環境および腐食速度}

本節では, 石炭滲出液の $\mathrm{pH}$ 測定およびイオンクロマト グラフィーによる陰イオンの定量分析を行い, 船倉内で局 部腐食の生じやすい環境を同定する。次に，石炭滲出液お よびこれを模擬する希硫酸環境における浸漬試験から腐食 速度を求め，石炭船倉内の腐食量を検討する。

\section{1 .1 石炭船倉の腐食環境の同定}

\section{（1）供試炭}

供試石炭は, 豪州（NSW 州）のグレイトグレタ炭であ る。石炭の元素分析によると, 全水分は $6.6 \%$, 全硫黄は $5.04 \%$, 灰分が $17.3 \%$ であり, 全硫黄のうち燃焼性硫黄 が $4.59 \%$, 不燃性硫黄が $0.44 \%$ ある。。扊分の化学成分 は, $\mathrm{SiO}_{2}, \mathrm{Fe}_{2} \mathrm{O}_{3}, \mathrm{Al}_{2} \mathrm{O}_{3}, \mathrm{CaO}, \mathrm{Na}_{2} \mathrm{O}$ などである。石炭滲出 液の試料とした粒径は, ふるいの網目 $5.6 \mathrm{~mm}$ を通過し ない塊とした。

（2）石炭滲出液の $\mathrm{pH}$

滲出液の作成には, 供試炭を超純水に浸漬し, 浸漬温度 および浸漬時間を変えるほか, 石炭と超純水との比率を変

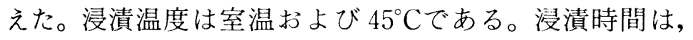
単に石炭粒を洗浄したものから一定時間または連続浸漬と した。

一例として, 石炭を $45^{\circ} \mathrm{C}$ の温度環境で浸漬した滲出液 の $\mathrm{pH}$ 経時変化を Fig. 2 に示す。Fig. 2 の滲出液は，石炭 と超純水それぞれ $500 \mathrm{gw}$ を試料瓶に入れ， $45^{\circ} \mathrm{C}$ の恒温水 槽に $24 ， 72,120$ および 192 時間浸漬後, 滲出液を回収し て実験室温状態に放置している。連続浸漬液は, 試料瓶を $45^{\circ} \mathrm{C}$ 恒温水槽に浸漬させたままの状態にある。したがっ て, 横軸の全時間は, 石炭の浸漬開始からの時間であり, 石炭浸漬時間と回収した滲出液の経過時間の合計を示す。

$\mathrm{pH}$ 変化は, 浸漬開始から増加するものと低下するもの の 2 グループがある。第 1 グループは, 浸漬時間が 120 時 間以下の滲出液である。 $\mathrm{pH}$ は, 浸漬 200 時間程度までに

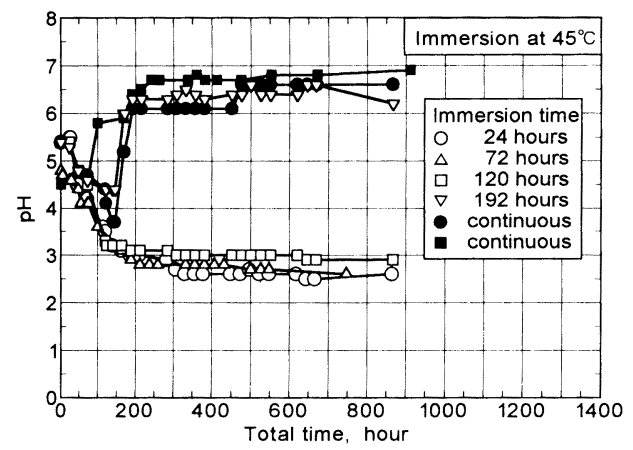

Fig. $2 \mathrm{pH}$ change with passage of time in exudation from coal at $45^{\circ} \mathrm{C}$
急激に低下し, それ以上の経時に対して変化がなく, 終点 が $\mathrm{pH}$ 3 2.5 程度に保持されている。第 2 グループは, 浸漬時間が 192 時間以上の滲出液に見られ, $\mathrm{pH}$ が 6.5 程 度に増加している。 $\mathrm{pH}$ の増加に見られる特徴は, $\mathrm{pH}$ が 浸漬開始時には低下する傾向にあるが，浸漬 150 時間から 200 時間にかけて増加することである。これは, 150 時間 以内に石炭から酸性物質が滲出するが, さらに浸漬し続け ると中和物質も滲出してくるものと推定される。なお, $45^{\circ} \mathrm{C}$ 連続浸漬では, 石炭と水の重量比を $2: 1,1: 2$ お よび 1: 4 と変えても, 重量比 $1: 1$ の Fig. 2 と $\mathrm{pH}$ の経 時変化は同様であり, 滲出液の濃度比が $\mathrm{pH}$ 変化に及ぼす 影響は見られなかった。

滲出液の $\mathrm{pH}$ 変化を室温で浸漬した結果と合わせて考え ると, 次のようにまとめられる。滲出液は, 温度が室温よ り高いと短時間に酸性化が促進されるが, 逆に室温より高 い液温での連続浸漬では浸漬液の中性化を促進する効果が あると言える。また, 温度環境が滲出液の酸性化に微妙な 影響を及ぼしている。

種々の滲出液による $\mathrm{pH}$ 変化を石炭船倉環境に照らす と, 次のような結果となる。第 1 に, 石炭滲出液の酸性化 は, 温度が影響している。第 2 に, 石炭の連続浸漬による 滲出液は, 中性化に向かうが, 加熱されると中性化が促進 される。第 $3 に$, 石炭から短時間に滲出する液は, $\mathrm{pH} 2.5$ 程度の酸性になる。これらのうち, 石炭船倉で最 も生じやすい環境は，第 3 の $\mathrm{pH}$ 低下に相当すると考えら れ, 室温から $45^{\circ} \mathrm{C}$ 程度の温度条件で石炭からの蒸発気体 が船側外板で結露して希硫酸となることは十分考えられ る。

\section{（3）石炭滲出液の分析}

石炭滲出液を酸性化させているイオンを検出するため, 滲出液を濾過し， $\mathrm{n}$ ヘキサンを用いた溶媒抽出により有 機物を除去し，イオンクロマトグラフによる陰イオン分析 を行った。そのイオンクロマトグラムを Fig. 3 に示す。

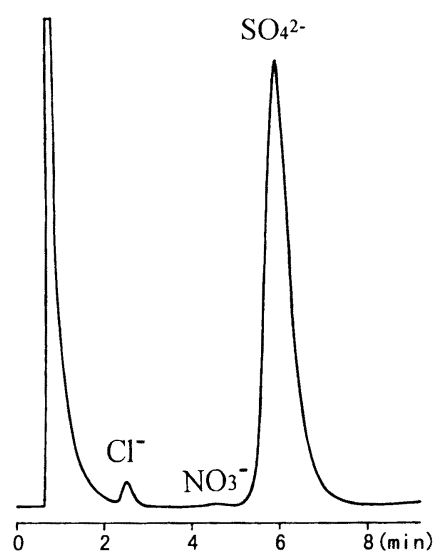

Fig. 3 Anion analysis of exudation solution from coal 
陰イオンは, $\mathrm{SO}_{4}{ }^{2-}$ が $99 \%$ 以上 $(3000 〜 3200$ 質量 ppm) であり, $\mathrm{Cl}^{-}$および $\mathrm{NO}_{3}^{-}$が極微量であった。また, $90^{\circ} \mathrm{C}$ で 1 時間加熱した滲出液の分析結果もまた同様の傾向にあ った。このことから, 滲出液の酸性物質は硫酸化合物であ ると判定される。

次に，硫酸化合物がどのような物質であるかの同定を試 みた。その手法は, 石炭中に存在が予想される硫酸化合物 の水溶液を試薬から作成し, 石炭からの滲出液と性状を比 較するものである。性状比較の試薬は, 次の 7 種類, すな わち硫酸第一鉄 $\mathrm{FeSO}_{4} \cdot 7 \mathrm{H}_{2} \mathrm{O}$, 硫酸第一鉄アンモニウム $\mathrm{Fe}\left(\mathrm{NH}_{4}\right)_{2}\left(\mathrm{SO}_{4}\right)_{2} \cdot 6 \mathrm{H}_{2} \mathrm{O}$, 硫酸アンモニウム $\left(\mathrm{NH}_{4}\right)_{2} \mathrm{SO}_{4}$, 硫酸カルシウム $\mathrm{CaSO}_{4} \cdot 2 \mathrm{H}_{2} \mathrm{O}$, 硫酸カリウム $\mathrm{K}_{2} \mathrm{SO}_{4}$, 硫 酸マグネシウム $\mathrm{MgSO}_{4} \cdot 7 \mathrm{H}_{2} \mathrm{O}$, 硫酸ナトリウム $\mathrm{Na}_{2} \mathrm{SO}_{4}$ とした。まず,これらの $5 \%$ 水溶液とその加熱液につい て, pH の経時変化や目視観察から性状を調査した。硫酸 化合物水溶液の $\mathrm{pH}$ が，500 時間後に低下したものは，硫 酸第一鉄の水溶液とその加熱液が $\mathrm{pH} 2.9$, 硫酸第一鉄ア ンモニウムの水溶液とその加熱液が $\mathrm{pH} 3.0$, 硫酸アンモ ニウム水溶液の加熱液が $\mathrm{pH} 3.3$ であった。

前述のように, 石炭からの滲出液は, 弱酸性から時間と ともに $\mathrm{pH}$ が低下し, 加熱液は $\mathrm{pH}$ が急激に低下してい る。さらに, 硫酸イオンは, 塩化バリウム $(5 \%)$ の添加 により白濁することから確認され, イオンクロマト分析か ら硫酸イオンが多量にあることが判明している。石炭滲出 液の濾過液は, 比色によると, 薄黄色から黄白色の沈殿を 生じて無色透明に変化している。石炭滲出液は, アクアチ エックによる比色試験では, 鉄イオンは検出されたが, 覀 硝酸および硝酸イオンは検出されなかった。また，パック テストの比色試験でも, 鉄イオンは検出されたがアンモ二 ウムイオンは検出されなかった。さらに, 滲出液を 1,000 倍まで希釈していき, 鉄イオンは数百 $\mathrm{ppm}$ 程度存在して いることが判明した。前述の試薬から作成した水溶液につ いてもアクアチェックとパックテストを行った。この結 果, 石炭滲出液からは, 鉄イオンは検出されるがアンモ二 ウムイオンが検出されないこと, 黄褐色の沈殿物が生じる ことから, 石炭滲出液の酸性は硫酸第一鉄による可能性が 最も高いと考えられる。

\section{1 .2 希硫酸環境の腐食速度}

\section{（1）腐食速度の算定方法}

腐食速度は, 研磨面 (TP), ショットブラスト面(TS) 抢 よびプライマー面(TC)を評価対象とする。浸漬試験によ る平均腐食速度 Rc は, 腐食減量から次のように計算し た。研磨面の腐食減量は, 試験片全表面が一様に減量する ものとする。ショットブラスト面の腐食減量は, 試験片側 面の研磨面の腐食減量を差し引き，ショットブラスト面の みを算定する。プライマー面の腐食減量は, 試験片側面の 研磨面の腐食減量を差し引くほか, 浸漬試験におけるプラ イマーの劣化状況, すなわちプライマー面に露出したショ
ットブラスト面を面積で補正して算定する。なお，腐食試 験片の除錆には，くえん酸二アンモニウム水溶液 10\%を 用いており，それぞれの腐食対象面に対する除錆に伴うブ ランク減量を差し引いている。

（2）希硫酸環境における腐食速度

希硫酸 $\mathrm{pH} 4$ 環境の腐食速度の経時変化を Fig. 4 に示 す。研磨面(TP)の腐食速度は, 浸漬 800 時間まではほほ $0.3 \mathrm{~mm} /$ yearであるが, 浸漬 2,000 時間以上でほほ 0.2 $\mathrm{mm} /$ yearである。ショットブラスト面(TS)の腐食速度 は, 浸漬 1,000〜3,000 時間のとき研磨面の Rcより大き く, 0.35〜0.38 mm/year となった。コーティングは, 浸 漬 2,500 時間後には完全に消滅している。したがって, 浸 漬 2,500 時間を超えるプライマ一面(TC)の腐食速度は, ショットブラスト面の腐食速度を示していると見られる。

ショットブラスト面の腐食速度が浸漬 1,000 時間以上で 大きくなったのは, 腐食減量の計算において, 試験片側面 の研磨面に対する腐食速度の補正法に問題があったと考え られる。ショットブラスト面の腐食速度は, 研磨面の腐食 速度を小さく見積もるか大きく見積もるかによって変わっ てくる。希硫酸中では鉄は激しく溶解するが, 腐食溶解の 異なる表面（研磨面とショットブラスト面）をもつ試験片 を同一の環境に浸漬したとき，それぞれの表面が独立して 溶解しない。すなわち, 研磨面とショットブラスト面が 様々な系の局部電池を形成していると考えられる。したが って, ショットブラスト面の腐食速度の算定には, 研磨面 の腐食減量をやや大きく見積もる必要があるかもしれな w。

希硫酸 pH 2 環境の腐食速度の経時変化を Fig. 5 に示 す。浸漬 1,500 時間を超える腐食速度は, 表面形態に関係 なく,ほぼ $5.5 \mathrm{~mm} /$ year の一定値を示した。無機ジンク ショッププライマーは, 336 時間で消滅している。このこ とからも, 腐食速度の大きい $\mathrm{pH} 2$ 環境は, 表面層が短時 間の浸漬で溶解し, どの表面もほぼ同等の溶解条件になっ ていると考えられる。希硫酸 $\mathrm{pH} 3$ 環境の腐食速度の経時 変化もまた, $\mathrm{pH} 2$ 環境と類似していた。

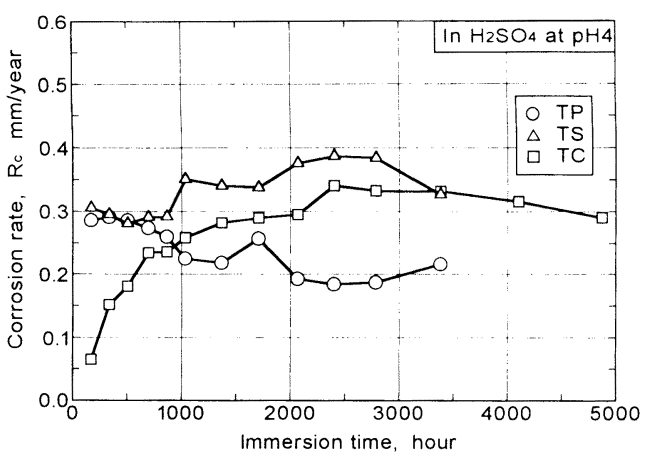

Fig. 4 Corrosion rate in dilute sulfuric acid at $\mathrm{pH} 4$ 


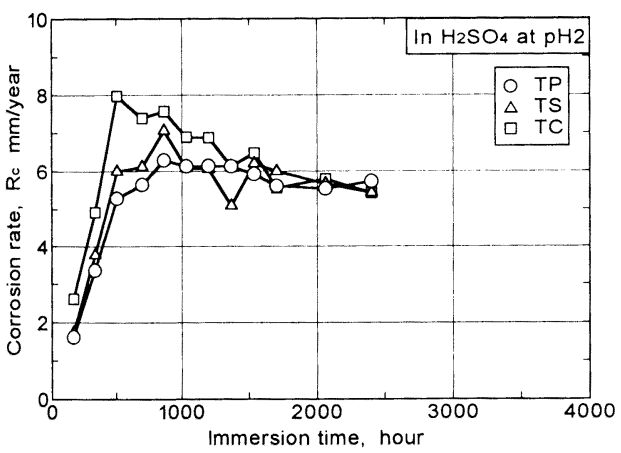

Fig. 5 Corrosion rate in dilute sulfuric acid at $\mathrm{pH} 2$

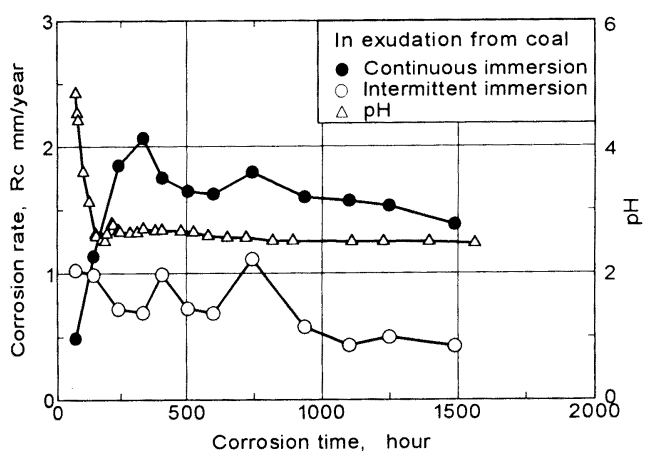

Fig. 6 Corrosion rate and $\mathrm{pH}$ change in exudation solution from coal

\section{（3）石炭滲出液における腐食速度}

石炭滲出液における腐食速度と pH の経時変化を Fig. 6 に示す。滃出液は，石炭と超純水それぞれ $130 \mathrm{~kg}$ を室温 で 72 時間浸漬して作成した。pH は, 浸漬試験中の試験 液を測定したものであり，250 時間後 pH 2.5〜2.6に低下 し, 以後試験中一定值を保持していた。連続浸漬試験の腐 食速度は, 試験当初に $\mathrm{pH}$ の低下とともに増加しており, 500 1,500 時間值が $1.6 \sim 1.5 \mathrm{~mm} /$ year である。間欠浸 漬の腐食速度は，500 時間值において連続浸漬の $1 / 2$ 程度 である。しかし，間欠浸漬時間は $1 \mathrm{~h} /$ day であり， $23 \mathrm{~h} /$ day が湿潤状態で大気中に暴露される状態では相当大きな 腐食速度になることを示している。Fig. 7 には，腐食時間 に対する単位面積当たりの腐食減量を示した。連続および 間欠浸漬とも 1,000 時間程度までは，腐食減量と腐食時間 が直線関係にある。

（4） pH と腐食速度の関係および石炭倉内の腐食量

腐食環境の $\mathrm{pH}$ に注目し，腐食速度と $\mathrm{pH}$ との関係を Fig. 8 に示す。前報) で得られた人工海水 $\mathrm{pH} 8.2$ の腐食 速度を含めて, 両者の関係を最小二乗法から求めると (1) 式で表される。○印は, 石炭滲出液による腐食速度であ り，(1)式からほぼ推定できると言える。したがって，石

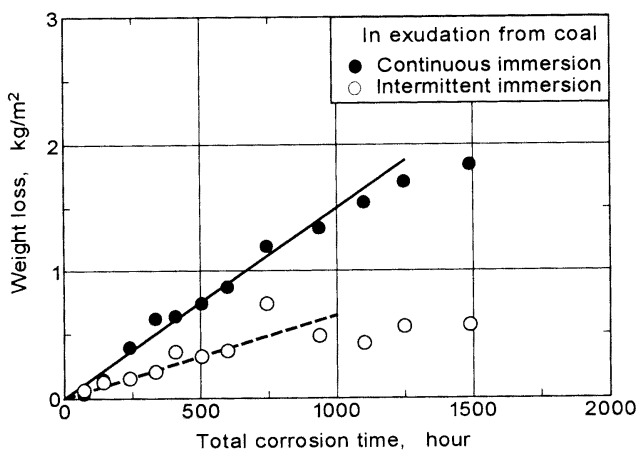

Fig. 7 Weight loss in exudation solution from coal

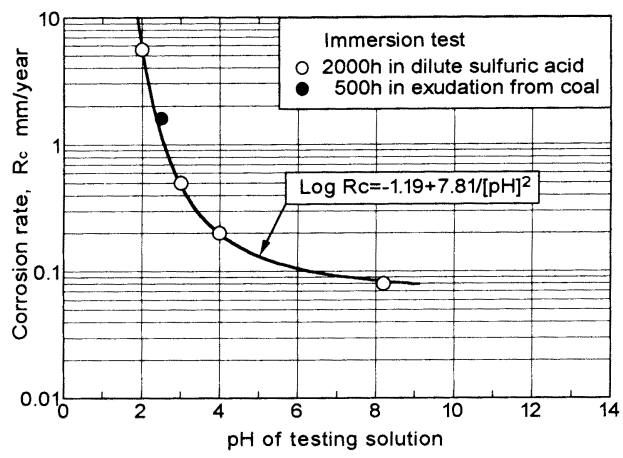

Fig. 8 Effect of $\mathrm{pH}$ on corrosion rate

炭滲出液による腐食速度は, 希硫酸の $\mathrm{pH}$ 環境で模擬する ことができる。

$\log R_{c}=-1.19+7.81 /[\mathrm{pH}]^{2}$

次に，豪州航路の石炭輸送期間を 2 週間（約 340 時間） とし，その間における局部腐食を検討する。この輸送期間 中に石炭からの滲出液は, Fig. 6 に見られたように, pH 2.5 に低下し, その腐食速度は連続浸漬を採用すると $1.6 \mathrm{~mm} /$ year である。この腐食速度に対する 1 航海の腐 食溶解量は $0.0621 \mathrm{~mm}$ となり, 年 12 回運行すると年間 腐食量は $0.75 \mathrm{~mm}$ となる。この腐食量は, 海水環境にお ける船舶の年間平均腐食速度の 7.5 倍である。この結果か ら，無塗装の船倉内で局部腐食の生じることが十分考えら れる。

\section{2 希硫酸環境の腐食疲労強度}

本節では, 希硫酸環境の疲労試験結果について, 公称応 力の S-N 線図, 修正 MIL HDBK 5 による等価応力とき 裂発生寿命の関係および切欠き底のき裂深さ $1 \mathrm{~mm}$ の応 力拡大係数範囲とき裂発生寿命の関係を検討する。また， 希硫酸環境におけるき裂進展特性, 実海域の繰返し速度に おけるき裂進展速度を検討する。

疲労き裂発生寿命は, 直流電位差から求めたき裂断面積 が $10 \mathrm{~mm}^{2}$ のときの繰返し数であり, 切欠き底の板厚貫通 
き裂深さが $1 \mathrm{~mm}$ に相当する。

\section{2 .1 腐食疲労試験結果}

(1) 公称応力の $S-N$ 線図

希硫酸 $\mathrm{pH} 4$ 抢よび $\mathrm{pH} 2$ 環境に抢ける公称応力範囲 $\Delta S$ とき裂発生寿命 $N_{c}$ おょび破断寿命 $N_{f}$ との関係をプ ロットし, Fig. 9 およびFig. 10 に示す。実線は $N_{c}$ に対 する回帰直線である。希硫酸 $\mathrm{pH} 2$ 環境の $K_{t}=1.2$ を除 き, いずれの $S-N$ 線図も低応力範囲になるに従い接近 し, 腐食疲労強度に及ほす $K_{t}$ の影響が小さくなってい る。希硫酸 $\mathrm{pH} 4$ 環境では, $\Delta S<100 \mathrm{MPa} の N_{c}$ が $S-N$ 線図の回帰直線からのびる傾向にある。これら希硫酸環境 の $S-N$ 線図は，海水腐食環境のそれら ${ }^{3)} に$ 類似してい る。

\section{（2）希硫酸環境の腐食ピット}

希硫酸環境における疲労き裂が, 腐食ピット底から発生 することは海水環境と同様である。海水環境と比較し, 特 徵ある希硫酸環境の腐食ピットを次に示す。

希硫酸 $\mathrm{pH} 4$ 環境において, 負荷応力範囲が高く短時間 (118 時間) に破断した試験片 $K_{t}=2.0\left(\Delta S=300 \mathrm{MPa}, N_{c}\right.$ $\left.=6.44 \times 10^{4}, N_{f}=7.08 \times 10^{4}\right)$ の切欠き底に形成された腐食

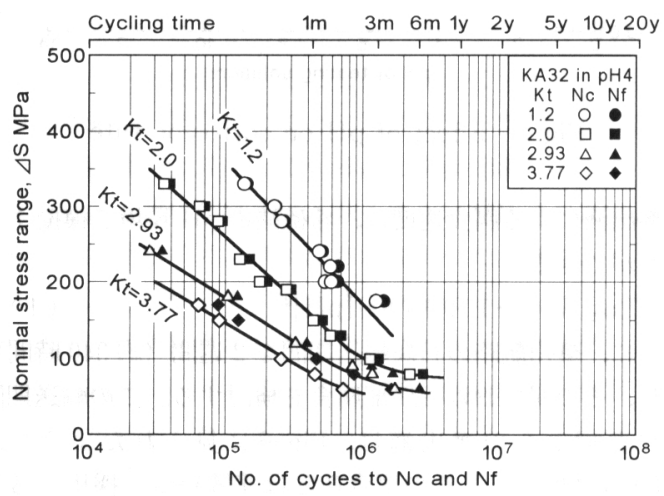

Fig. $9 S-N$ curves in $\mathrm{H}_{2} \mathrm{SO}_{4}$ at $\mathrm{pH} 4$

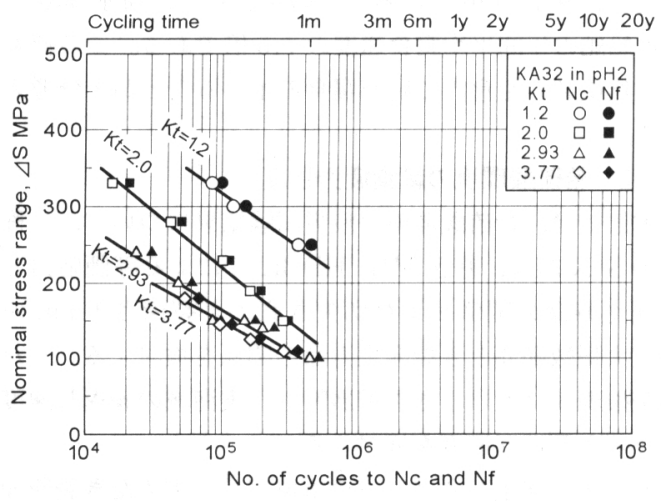

Fig. $10 \quad S-N$ curves in $\mathrm{H}_{2} \mathrm{SO}_{4}$ at $\mathrm{pH} 2$
ピットを，Fig. 11 に示す。Fig. 11 は，疲労破壞した切欠 き底付近に観察される腐食ピットである。これら腐食ピッ トはいずれも負荷方向と直角に形成され，ピットの先端が 鋭く引きちぎられたような形状である。Fig. 12 は, Fig. 11 の破面であり, Fig. 11 の腐食ピットが切欠き底から深 く成長している様子がわかる。さらに, 破断面の腐食ピッ
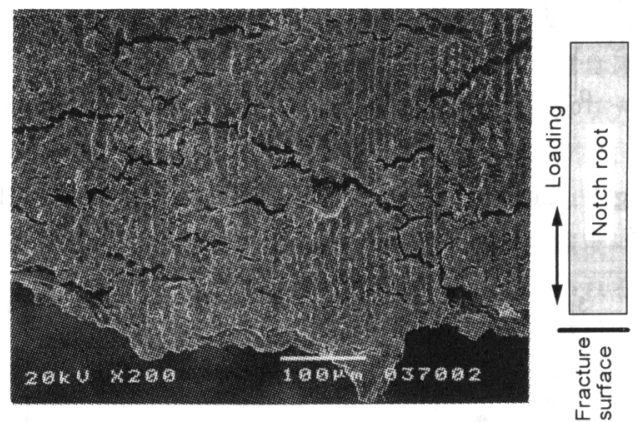

Fig. 11 Corrosion pits with sharp front end in $\mathrm{H}_{2} \mathrm{SO}_{4}$ at $\mathrm{pH} 4\left(K_{t}=2.0, \Delta S=300 \mathrm{MPa}, N_{c}=6.44 \times 10^{4}, N_{f}\right.$ $\left.=7.08 \times 10^{4}\right)$

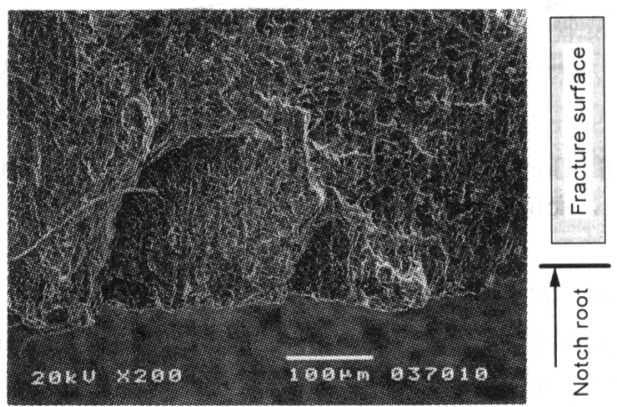

Fig. 12 Grown-up pits during crack growth in $\mathrm{H}_{2} \mathrm{SO}_{4}$ at $\mathrm{pH} 4$

$\left(K_{t}=2.0, \Delta S=300 \mathrm{MPa}, N_{c}=6.44 \times 10^{4}, N_{f}=\right.$ $\left.7.08 \times 10^{4}\right)$

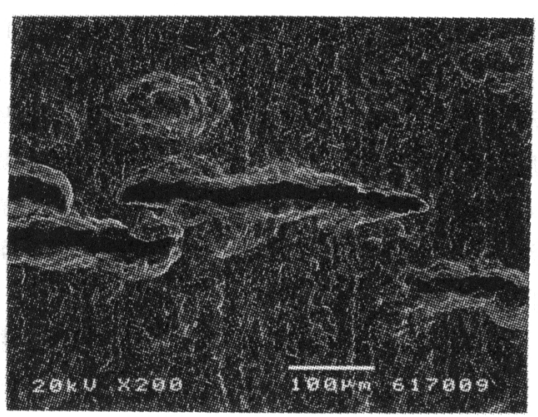

Fig. 13 Expanded view of corrosion pits with round front end in $\mathrm{H}_{2} \mathrm{SO}_{4}$ at $\mathrm{pH} 4$ $\left(K_{t}=1.2, \Delta S=220 \mathrm{MPa}, N_{c}=5.87 \times 10^{5}, N_{f}=\right.$ $\left.6.69 \times 10^{5}\right)$ 
トには成長の核となった小さなピットが観察される。Fig. 13 は, 長時間 $\left(1,115\right.$ 時間) で破断した試験片 $K_{t}=$ $1.2\left(\Delta S=220 \mathrm{MPa}, N_{c}=5.87 \times 10^{5}, N_{f}=6.69 \times 10^{5}\right)$ の切久 き底に形成された腐食ピットである。上述の Fig. 11 と比 較し，表面の腐食ピット端は丸みをもっている。しかし， この腐食ピットもまた深さ方向に深く成長していた。

他の腐食ピットの観察結果も含めて, 希硫酸環境の腐食 ピットについては, 次のようにまとめられる。すなわち, 切欠き底の負荷応力が降伏点を超えるような場合は, 短時 間で破断するため切欠き底表面の腐食溶解は少ないが, き 裂の進展過程で深いピットとして成長する。長時間の腐食 疲労では, 腐食ピットが深く成長するが, 応力集中が大き いと腐食溶解が大きく, 応力集中が小さいと腐食溶解が少 ない。腐食疲労き裂の発生起点は, 核となる腐食ピットか らである。腐食ピットは, 深さ方向に成長して疲労き裂と なる。

（3）腐食ピットからの疲労き裂発生条件

駒井らは, HT 50-CR の海水腐食疲労において, 腐食ピ ットから疲労き裂が発生する力学的条件を得ている。その 結果では, 疲労き裂発生の腐食ピットのアスペクト比が 0.65 で, その応力拡大係数範囲 $\Delta \mathrm{K}_{\mathrm{CF}}$ が $1.71 \mathrm{MPa} \cdot \mathrm{m}^{1 / 2}$ であると報告されている7)。

以下, 希硫酸環境での疲労き裂発生条件を検討する。上 述までの疲労破面は, 疲労破断後に観察したものである が, き裂の起点となった腐食ピットにはき裂進展に伴うピ ット成長の痕跡とともにき裂発生の核となったピットが確 認できる。そこで, この核に対する腐食ピットの形状を SEM 写真から読みとり, 腐食ピット深さ $a_{p}$ と表面ピッ ト長さの $1 / 2$ を $c_{p}$ として Fig. 14 にプロットした。腐食 ピットのアスペクト比 $\lambda\left(=a_{p} / c_{p}\right)$ は, $0.2 \sim 0.8$ にばらつ いている。その平均值は, ほぼ 0.4 程度である。また, 希 硫酸 $\mathrm{pH} 2$ 環境の入は, 希硫酸 $\mathrm{pH} 4$ 環境のそれより小さ いが, 深い腐食ピットでき裂発生となる。

次に, 切欠き底の腐食ピットを表面き裂と見なしたとき

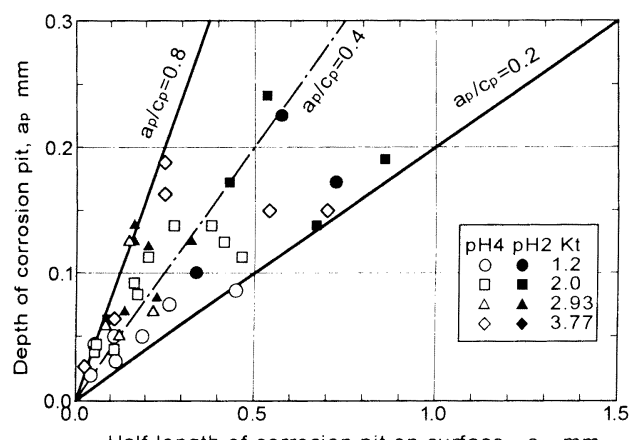

Half length of corrosion pit on surface, $\mathrm{cp} \mathrm{mm}$

Fig. 14 Aspect ratio of corrosion pit in dilute sulfuric acid
のき裂発生条件，すなわち疲労き裂発生の腐食ピットに対 する応力拡大係数範囲 $\Delta \mathrm{K}_{\mathrm{CF}}$ を求める。 $\Delta \mathrm{K}_{\mathrm{CF}}$ は, 村上 $ら^{8)}$ が解析した応力集中部に存在する半楕円形状の表面き 裂を腐食ピットと見なして求めた。この応力拡大係数は, 軸力と曲げ成分の和として求められるが, 切欠き底の負荷 応力が大きくき裂深さが小さいことから，ほとんどが軸力 成分である。 $\Delta \mathrm{K}_{\mathrm{CF}}$ と $a_{p}$ との関係を Fig. 15 に示す。

$\Delta \mathrm{K}_{\mathrm{CF}}$ は， $a_{p}$ が大きくなれば大きくなる傾向がある。また $\Delta \mathrm{K}_{\mathrm{CF}}$ には， $\mathrm{K}_{\mathrm{t}}$ や腐食環境の相違も見られる。 $\Delta \mathrm{K}_{\mathrm{CF}}$ 計算 の補正係数は, 希硫酸 $\mathrm{pH} 2$ および $\mathrm{pH} 4$ 環境がそれぞれ 0.79 および 0.80 であり，アスペクト比にばらつきがあつ ても補正係数のばらつきは小さい。したがって， $\Delta \mathrm{K}_{\mathrm{CF}}$ の 差は, 腐食ピット深さ $a_{p}$ の相違によるものと考えられ る。結局, 疲労き裂発生の $a_{p}$ には, ピット先端の鋭さや 切欠き底の応力勾配が影響を及ぼすから, 腐食環境と負荷 応力に対するピット成長速度について詳細な検討が必要で あると考える。いま, 希硫酸環境における腐食疲労のき裂 発生条件として，上述の $a_{p}$ が $\Delta \mathrm{K}_{\mathrm{CF}}$ に及ぼす影響を無視 し, $\Delta \mathrm{K}_{\mathrm{CF}}$ の平均值を採用すると, 希硫酸 $\mathrm{pH} 4$ 環境が $3.60 \mathrm{MPa} \cdot \mathrm{m}^{1 / 2}$, 希硫酸 $\mathrm{pH} 2$ 環境が $5.39 \mathrm{MPa} \cdot \mathrm{m}^{1 / 2}$ とな る。

\section{2 .2 等価応力による腐食疲労強度}

切欠き材の海水腐食疲労では, 修正 MIL HDBK 5 法 による等洒応力 $S_{e q}$ と $N_{c}$ の関係が, $\mathrm{K}_{t}$ に関わりなく, 勾配の異なる 2 本の折れ線に統合される結果を得て, き裂 発生機構を理解することができた ${ }^{3)}$ 。この手法と同様に, 希硫酸環境における切欠き試験片の $S_{e q} / \mathrm{N}_{c}$ 線図を Fig. 16 に示す。同図には, 大気中, 海水中, 突合せ溶接継手およ び横隅肉溶接継手の $S_{e q} / N_{c}$ 線図を併記した。また, 等価 応力 $L_{u y}$ および $L_{l y}$ を点線で示した。 $R=0.1$ で弾性状態 を仮定すると, $L_{u y}$ は最大応力 * $S_{\max }$ が砂時計試験片の繰 返し載荷におけるピーク值の真応力ーひずみ関係における 塑性開始応力 $\sigma_{p s}$ となる等価応力 $(440 \mathrm{MPa})$ であり, $L_{l y}$ は* $S_{\max }$ が平板試験片の下降伏点 $S_{l y}$ となる等価応力 (340 MPa) である。

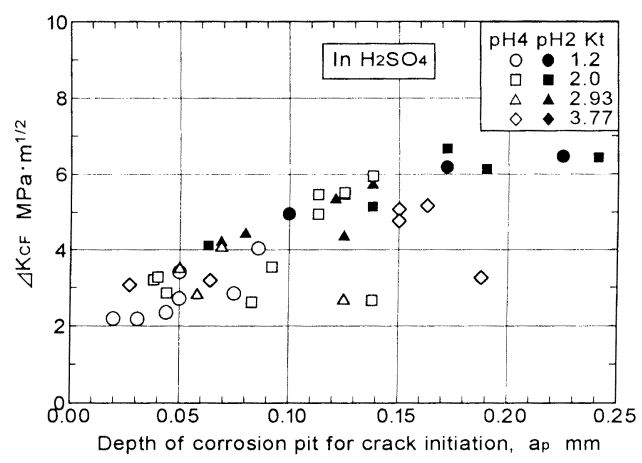

Fig. 15 Relationships between $\Delta K_{C F}$ and $a_{p}$ 


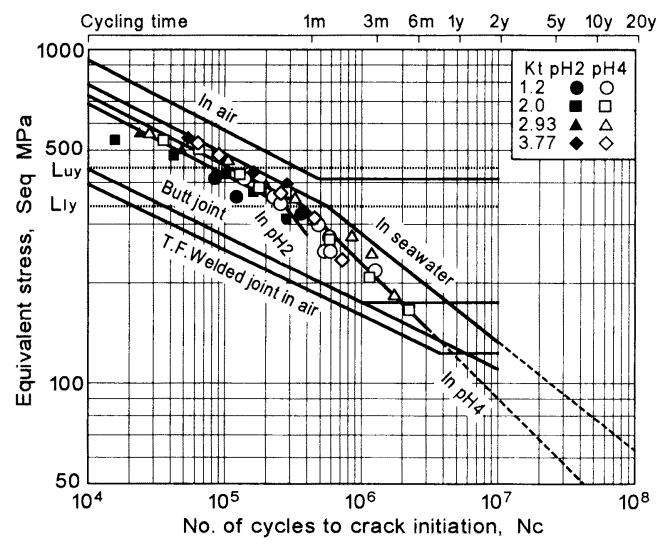

Fig. 16 Relationships between $S_{e q}$ and $N_{c}$ in $\mathrm{H}_{2} \mathrm{SO}_{4}$ at $\mathrm{pH} 4$ and at $\mathrm{pH} 2$

Table 3 Constants $C_{e}$ and $\mathrm{k}$ for equation $S_{e q}=C_{e} N_{c}^{k}$

\begin{tabular}{|c|c|c|c|c|}
\hline & Env. & $\mathrm{Ce}$ & $\mathrm{k}$ & $\begin{array}{l}\text { Applicable } \\
\text { range, Nc }\end{array}$ \\
\hline \multirow{4}{*}{$\begin{array}{l}\text { Notched } \\
\text { specimen }\end{array}$} & In air & 6,500 & -0.2110 & $<5.2 \times 10^{5}$ \\
\hline & In sw. & $\begin{array}{r}5,350 \\
24,780\end{array}$ & \begin{tabular}{|l|}
-0.2083 \\
-0.3244
\end{tabular} & $\begin{array}{l}<5.5 \times 10^{5} \\
>5.5 \times 10^{5}\end{array}$ \\
\hline & $\begin{array}{l}\text { In } \mathrm{H}_{2} \mathrm{SO}_{4} \\
\text { at } \mathrm{pH} 4\end{array}$ & $\begin{array}{r}5,053 \\
62,670\end{array}$ & \begin{tabular}{|l|}
-0.2101 \\
-0.4061
\end{tabular} & $\begin{array}{l}<3.8 \times 10^{5} \\
>3.8 \times 10^{5}\end{array}$ \\
\hline & $\begin{array}{l}\text { In } \mathrm{H}_{2} \mathrm{SO}_{4} \\
\text { at } \mathrm{pH} 2\end{array}$ & 4,893 & -0.2130 & $<2.7 \times 10^{5}$ \\
\hline $\begin{array}{l}\text { Butt } \\
\text { welded j. }\end{array}$ & $\begin{array}{l}\text { In air } \\
\text { In sw. }\end{array}$ & $\begin{array}{l}2,770 \\
2,770\end{array}$ & $\begin{array}{r}-0.2000 \\
-0.2000\end{array}$ & $\begin{array}{l}<1 \times 10^{6} \\
<3 \times 10^{6}\end{array}$ \\
\hline $\begin{array}{l}\text { T.Fillet } \\
\text { welded } \mathrm{j} \text { * }\end{array}$ & In air & 2,421 & -0.1967 & $<3.5 \times 10^{6}$ \\
\hline
\end{tabular}

*(Matsuoka and Fujii Ref. 9)

これらの環境に抢ける $S_{e q} / N_{c}$ 線図は，（2）式で表され， その定数 $C_{e}$ 抢よび指数 $k$ を Table 3 亿示す。 $S_{e q} / N_{c}$ 線 図は, $L_{l y}$ で折れ曲がるため, $S_{e q}>L_{l y}$ と $S_{e q}<L_{l y}$ の範 囲に分けて検討する。

$$
S_{e q}=C e N c^{k}
$$

（1） $S_{e q}>L_{l y}$ の範囲の $S_{e q} / N_{c}$ 線図

勾配は, 希硫酸 $\mathrm{pH}$ の相違により若干の相違が見られる ものの, 大気中, 海水中および溶接継手にほぼ等しい。き 裂発生寿命は, 海水腐食疲労より $\mathrm{pH}$ の低下とともに短寿 命となっている。き裂発生寿命のばらつきは, pH 4 環境 が小さいのに対し pH 2 環境が大きい。 $\mathrm{pH} 2$ 環境のき裂 発生寿命は $K_{t}$ が大きいほど長寿命となる傾向がある。

希硫酸環境の公配が海水環境や大気中のそれに等しいこ とは, この範囲での希硫酸環境のき裂発生機構が海水環境 や大気中のそれと基本的に変わらないものと考えられる。
すなわち, 試験片表面の加工傷に腐食溶解が加わり，腐食 ピットからき裂が発生する。き裂発生寿命が $\mathrm{pH}$ の低下と ともに短寿命となるのは, 試験環境による腐食ピットの成 長速度の差と考元られる。希硫酸 $\mathrm{pH} 2$ 環境のき裂発生寿 命のばらつき要因は, 腐食溶解が負荷応力に及ぼす影響と 考えられる。すなわち， $K_{t}=3.77$ の切欠き底は， $K_{t}=1.2$ の形状と比較して深いき裂と見なされ，腐食溶解が大きい ためにピット先端が鈍化し, 進展する疲労き裂に成長しに くいことが考えられる。

また, $L_{u y}>S_{e q}>L_{l y}$ の範囲におけるき裂発生寿命のば らつきは, 海水腐食疲労では大きかったものが希硫酸環境 では小さい。これは, 腐食溶解速度が海水環境より希硫酸 環境で大きいためであり, き裂停留の生じる余地が全くな いためと考えられる。

(2) $S_{e q}<L_{l y}$ の範囲の $S_{e q} / N_{c}$ 線図

希硫酸 $\mathrm{pH} 4$ 環境の勾配が $L_{1 y}$ を境にして大きく異なっ ている点は, 海水腐食疲労と同様の傾向である。 $\mathrm{pH} 4$ 環 境の公配は, 海水腐食疲労上り相当大きい。これは, 腐食 ピットの成長速度が大きいためと考えられる。希硫酸 $\mathrm{pH} 2$ 環境では, 実験点は少ないが, き裂発生寿命は希硫 酸 $\mathrm{pH} 4$ より短寿命である。そのため, 勾配は, $\mathrm{pH} 4$ 環 境のそれよりさらに大きくなるものと推定されるが, 低応 力範囲の腐食疲労では, 腐食溶解による負荷応力の増加が 影響してくる。

以上のように, 希硫酸環境の疲労き裂発生寿命が海水環 境のそれより短寿命となるのは, 腐食速度が大きいことに よる。環境による腐食溶解速度の相違は, 疲労き裂発生段 階の腐食ピット成長に著しい影響を与えている。

4.2 .3 応力拡大係数範囲に上る腐食疲労強度

（1）希硫酸環境のき裂進展速度と $\Delta K$ との関係

希硫酸 $\mathrm{pH} 4$ および $\mathrm{pH} 3$ 環境におけるき裂進展速 dald $N$ と $\Delta K$ の関係を Fig. 17 にプロットし，大気中およ び海水中のき裂進展特性を実線で併記した。Paris 則 ( 3 ) 式の定数 $C$ 抢よび指数 $m$ を同図内に示す。

$$
d a / d N=C \Delta K^{m}
$$

希硫酸 $\mathrm{pH} 4$ 環境と $\mathrm{pH} 3$ 環境のき裂進展特性は, ほほ 等しい。Paris 則の $C$ および $m$ に注目すると，腐食環境 が㛜しくなるに従い $C$ は大きくなり， $m$ は小さくなる傾 向がある。しかし, 海水環境, 希硫酸 $\mathrm{pH} 4$ および $\mathrm{pH} 3$ 環境では Paris 則の成立する範囲のき裂進展特性に大きな 相違がないと言える。これらの環境におけるき裂進展特性 がほとんど変わらない要因は, き裂先端の腐食溶解機構に 深く係わっている。き裂進展に及ぼす環境の影響として, 遠藤・駒井 ${ }^{10)}$ は, 「き裂内の $O_{2}$ 不足, $\mathrm{Cl}^{-}$の濃縮, 金属 イオンの加水分解による $\mathrm{pH}$ の低下 (中性溶液中において も鋼や $\mathrm{Al}$ 合金のき裂先端の $\mathrm{pH}$ は 3 くらいまで低下して いる）などにより，き裂先端がアノードになり，外部はカ ソードとして作用し，き裂進展が促進される」と記してい 


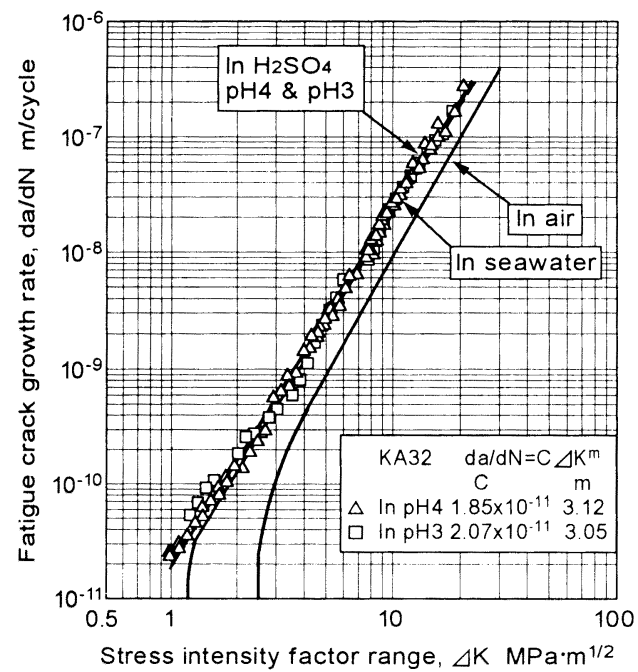

Fig. 17 Relationships between $d a / d N$ and $\Delta K$ in $\mathrm{H}_{2} \mathrm{SO}_{4}$ at $\mathrm{pH} 4$ and at $\mathrm{pH} 3$

る。このことを本実験結果に照らしてみると, 海水中のき 裂先端は, 希硫酸 $\mathrm{pH} 4$ または $\mathrm{pH} 3$ 環境と同程度の腐食 環境になっているとみて差し支えないと言える。

希硫酸 $\mathrm{pH} 4$ 環境の下限界応力拡大係数範囲 $\Delta K_{\mathrm{th}}$ 注, 求められていないが, 実験からは $0.98 \mathrm{MPa} \cdot \mathrm{m}^{1 / 2}$ より小

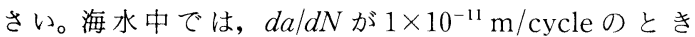
$\Delta K_{\mathrm{th}}$ を十分満足している。したがって, 希硫酸 $\mathrm{pH} 4$ 環 境の $\Delta K_{\mathrm{th}}$ を目安として Paris 則から求めると, $d a / d N=$ $1 \times 10^{-11} \mathrm{~m} /$ cycle の $\Delta K$ は $0.82 \mathrm{MPa} \cdot \mathrm{m}^{1 / 2}$ となる。

（2）海洋環境の繰返し速度に打けるき裂進展速度 実環境の繰返し速度におけるき裂進展速度と腐食溶解速 度の関連性を検討する。

駒井らは, 腐食疲労のき裂進展速度 $[d a / d N]_{\mathrm{CF}}$ が, 大気 中のき裂進展速度 $[d a / d N]_{F}$ と腐食溶解のみに依存する進 展速度 $[d a / d N]_{D}$ の和とする $(4)$ 式の線形加算則を提案し ている ${ }^{11,12 \%}$ 。

$$
[d a / d N]_{\mathrm{CF}}=[d a / d N]_{F}+[d a / d N]_{D}
$$

低応力長時間のき裂進展においては，腐食溶解が支配的と なるため, (4) 式の $[d a / d N]_{F}$ を 0 と見なし，腐食環境の き裂進展速度が, $[d a / d N]_{D}$ となる考え方である。また， 実構造物では, 疲労き裂の塑性誘起き裂閉口や腐食生成物 のくさび効果が期待できないので $\Delta K_{\mathrm{eff}}=\Delta K$ とみなし, 低応力長時間のき裂進展速度, すなわち $[d a / d N]_{D}$ が応力 助長腐食溶解速度 PGR になるとしている。さらに，PGR と腐食溶解進展速度 $[d a / d N]_{D}$ との交点 (Fig. 18 の点 $\mathrm{P}$ ) は, 腐食疲労き裂進展が明瞭な $\Delta K$ 依存性を示す下限界 值であり，この下限界值は腐食ピットからき裂が発生する 力学条件の下限界值 $\Delta K_{\mathrm{CF}}$ にほほ等しいとしている ${ }^{12}$ 。ま た，PGRは，腐食ピットの深さ成長速度を腐食速度 $R_{c}$

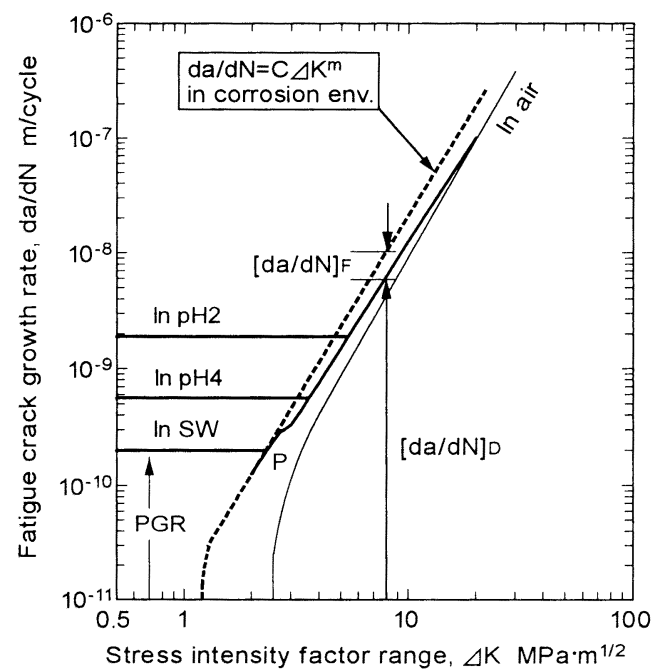

Fig. 18 Long-term corrosion fatigue crack growth rate in ocean environment

として, 周波数 $f$ から $(5)$ 式により計算される。

$[d a / d N]_{D}=R_{c} / f$

上記 PGR の考え方を Fig. 18 に示し, 実海洋環境の繰 返し速度における希硫酸環境の低応力長時間のき裂進展速 度を求める。Fig. 18 亿おいて, 細線は $[d a / d N]_{\mathrm{F}}-\Delta K$ 関 係である。破線は， $[d a / d N]_{\mathrm{CF}}$ であり，代表として海水環 境の $d a / d N-\Delta K$ 関係を示す。実線は腐食溶解が支配的と なる $[d a / d N]_{D}-\Delta K$ 関係である。海水環境の PGR $(=2 \times$ $10^{-10} \mathrm{~m} /$ cycle) は, 回転曲げ疲労試験における腐食ピット 深さ成長速度の平均值 $1.07 \mathrm{~mm} /$ year に対する $[d a / d N]_{D}$ である12)。

次に, 希硫酸 $\mathrm{pH} 4$ 抢よび $\mathrm{pH} 2$ 環境の $\mathrm{PGR}$ を求める。 本供試材の希硫酸環境における腐食ピットからのき裂発生 条件は，4.2.1 項のSEM 観察に打いて, 希硫酸 $\mathrm{pH} 4$ 打 よび $\mathrm{pH} 2$ 環境の $\Delta K_{\mathrm{CF}}$ がそれぞれ $3.60 \mathrm{MPa} ・ \mathrm{~m}^{1 / 2}$ および $5.39 \mathrm{MPa} \cdot \mathrm{m}^{1 / 2}$ と求めた。これらの $\Delta K_{\mathrm{CF}}$ に対する $[d a / d N]_{D}$ ，すなわち PGR は，(4)式からそれぞれ $5.63 \times$ $10^{-10} \mathrm{~m} /$ cycle 抢よび $1.90 \times 10^{-9} \mathrm{~m} /$ cycle となり, 海洋環 境 $0.17 \mathrm{~Hz}$ に㧍ける希硫酸 $\mathrm{pH} 4$ 抢よび $\mathrm{pH} 2$ 環境の腐食 き裂進展速度となる。これらの PGR を Fig. 18 亿示す。 希硫酸 $\mathrm{pH} 4$ 抢よび $\mathrm{pH} 2$ 環境のPGR は，それぞれ海水 環境のほほ 2.7 倍および 9.5 倍である。

一方, Akid と Miller ${ }^{13}$ は，駒井らと同様の考方方を提 案しており，(5)式の $R_{c}$ を腐食電流密度から得られる金 属溶解速度として求めている。4.1.2 項から浸漬 1,500 時 間の研磨面の腐食速度は，希硫酸 $\mathrm{pH} 4$ および $\mathrm{pH} 2$ 環境 がそれぞれ $0.2 \mathrm{~mm} /$ year 抢よび $5.5 \mathrm{~mm} /$ yearである。 これらの腐食速度が電気化学的に計測される腐食溶解速度 に等しいとしてAkidらの考え方に適用すると， 
$[\mathrm{d} a / d N]_{D}$ はそれぞれ $3.73 \times 10^{-11} \mathrm{~m} /$ cycle および $1.03 \times$ $10^{-9} \mathrm{~m} /$ cycle となる。これら浸漬試験の平均腐食速度か ら求めたき裂進展速度は, それぞれ $\Delta K_{\mathrm{CF}}$ に対する PGR の $6.8 \%$ および $54 \%$ であり，相当小さい。この相違は， Rc に浸漬試験の平均腐食速度を用いていることによると考え られる。しかし, 腐食溶解の大きい希硫酸 $\mathrm{pH} 2$ 環境の浸 漬試験からの PGR は， $\Delta K_{\mathrm{CF}}$ からの值にかなり近くなる。

また, 駒井らが求めた海水環境における腐食ピット深さ の成長速度 $1.07 \mathrm{~mm} /$ year は, 船舶などの年間平均腐食 速度の 10 倍である。腐食疲労では, 応力腐食割れ（SCC） を生じない場合, 疲労き裂の発生と進展に対して応力助長 腐食溶解が生じること ${ }^{14)}$, また微小き裂は長いき裂よりき 裂進展速度が極めて大きいこと胡が知られている。した がって, 低応力長寿命のき裂進展速度の推定には, 腐食溶 解速度としてどのような物理量を採用すべきかは今後の研 究に待つところとしたい。

\section{（3） $\Delta K-N_{c}$ 関係の腐食疲労強度}

前述の公称応力および等価応力の $S-N$ 線図から, 低応 力長寿命腐食疲労の下限值を見い出すには, 長時間の腐食 疲労試験が必要となる。そこで, 腐食疲労を $\Delta K / N_{c}$ 関係 で表すことの意義は，次のように説明できる。

長いき裂の進展特性は, 前項の Paris 則に見られたよう に，腐食環境条件の影響がほとんど見られない。切欠き底 のき裂深さ $1 \mathrm{~mm}$ に扔いて Paris 則が成立していれば，腐 食環境では， $\Delta K / N_{c}$ 関係の勾配が環境条件によらず $-1 / m$ の一定值になるはずである。同一形状試験片の一 定長さのき裂では， $\Delta K$ と $\Delta S$ は比例するため, き裂発生 寿命を基準とする $\Delta K / N_{c}$ 関係は， $S-N$ 関係と同様に扱う ことができる。 $S-N$ 関係の疲れ限度は, $\Delta K / N_{c}$ 関係の下 限界応力拡大係数範囲 $\Delta K_{t h}$ に相当する。これらの点か ら, 腐食疲労データの $\Delta K / N_{c}$ による整理は, 意義があ り, 有用性が高いと言えよう。以下, 希硫酸環境の腐食疲 労における $\Delta K / N_{c}$ 関係を検討する。

希硫酸 $\mathrm{pH} 4$ 環境において，（3 式の Paris 則から，十 分長いき裂が $1 \mathrm{~mm}$ 進展する $\Delta K / N$ 関係は ( 6 ) 式となる。

$$
\Delta K=313 N^{-1 / m}
$$

Paris 則の定数および指数は, 希硫酸 $\mathrm{pH} 4, \mathrm{pH} 3$ 環境お よび海水環境でほとんど変わらない。このことから，希硫 酸 $\mathrm{pH} 2$ 環境のき裂進展特性もまた希硫酸 $\mathrm{pH} 4$ 環境のそ れで代表できるものとし, 希硫酸 $\mathrm{pH} 2$ 環境の $\Delta K / N$ 線図 の勾配は，希硫酸 $\mathrm{pH} 4$ 環境の勾配を適用する。

希硫酸 $\mathrm{pH} 4$ および $\mathrm{pH} 2$ 環境における $\Delta K / N_{c}$ 関係をそ れぞれ Fig. 19 および Fig. 20 にプロットし， $K_{t}=1.2$ およ び 3.77 の $\Delta K / N_{c}$ 線図を実線で示す。 $N_{c}$ における $\Delta K$ は, 西谷らによる二次元応力解析沉用プログラム ${ }^{16)} に よ り$ 求 めた。両環境の $\Delta K / N_{c}$ 線図 $(7)$ 式の定数 $C_{c}$ は, 海水環 境の場合と同様に，腐食環境が微小き裂進展に及ぼす影響 が大きいので，それぞれ切欠き底の最大応力が弾性範囲の

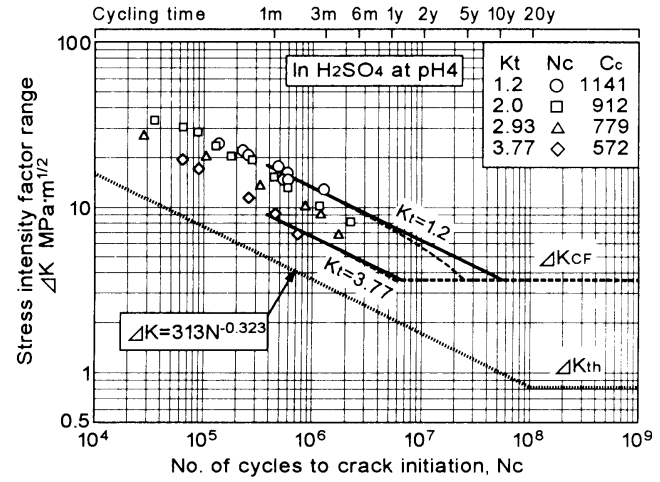

Fig. 19 Relationships between $\Delta K$ and $N_{c}$ in $\mathrm{H}_{2} \mathrm{SO}_{4}$ at $\mathrm{pH} 4$

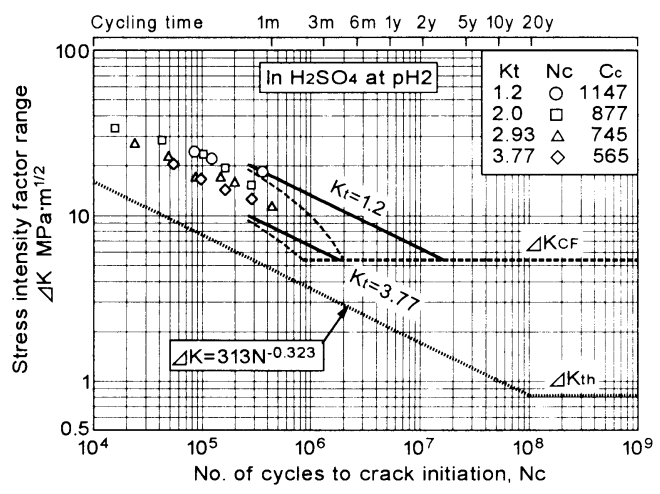

Fig. 20 Relationships between $\Delta K$ and $N_{c}$ in $\mathrm{H}_{2} \mathrm{SO}_{4}$ at $\mathrm{pH} 2$

実験值の平均值から求めた。この条件を満たす実験点は, $S_{e p} / N_{c}$ 線図の等価応力が $L_{l y}$ 以下に属する。したがって, $\Delta K / N_{c}$ 線図の実線は, 希硫酸 $\mathrm{pH} 4$ 環境が $N_{c}>3.8 \times 10^{5}$, 希硫酸 $\mathrm{pH} 2$ 環境が $N_{c}>2.7 \times 10^{5}$ の範囲について示した。 ただし, 希硫酸 pH 2 環境 Fig. 20 の $K_{t}=3.77$ では, 最大 応力が弾性範囲の実験は実施していないため, ( 7 )式の $C_{c}$ は, 後述に示す Fig. 21 の $C_{c}$ と $K_{t}$ の直線関係を外挿 して求めた。

$$
\Delta K=C_{c} N_{c}^{-1 / m}
$$

Fig. 19 抢よびFig. 20 において, $\Delta K / N_{c}$ 関係の実線は, 切欠き底の最大応力が降伏点を超える短寿命の実験範囲ま で延長できるように見える。この結果は, 前報の海水環境 の $\Delta K / N_{c}$ 関係が切欠き底の負荷応力が弾性範囲にあるか ないかによって明確に異なるのと対照的である。この要因 としては, 希硫酸環境の切欠き底の腐食溶解速度が海水環 境のそれより大きいこと以外は考えられない。すなわち， 高応力範囲の試験においては, 切欠き底の塑性域が腐食溶 解することにより加工傷や腐食ピット先端を鈍化させ，き 裂発生が抑制されていると考えられる。 


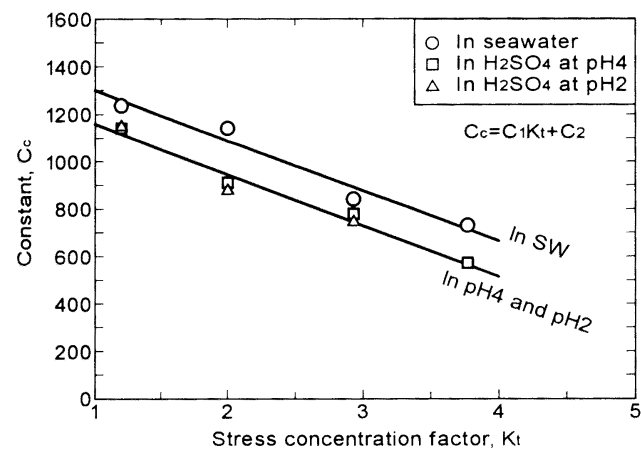

Fig. 21 Relationships between $C_{c}$ and $K_{t}$

本実験における $(7)$ 式の分这数 $C_{c}$ と $K_{t}$ の関係を Fig. 21 にプロットした。希硫酸環境のCには， pH 4 と $\mathrm{pH} 2$ 環 境の相違がほとんど見られない。C 海水環境㧍よび希硫酸環境とも $C_{1}$ および $C_{2}$ を定数とす る(8)式の直線関係で寺えられる。

$$
C_{c}=C_{1} K_{t}+C_{2}
$$

勾配を示す $C_{1}$ は, 海水環境と希硫酸環境ともほぼ等し い。強度レベル $\Delta K$ を示す定数 $C_{2}$ は, 希硫酸環境が海水 環境 $\mathrm{pH} 8.2$ より低下している。 $C_{1}$ が海水環境と希硫酸 環境でほぼ等しいのは， $\Delta K / N_{c}$ 線爫の公配 $-1 / m$ がほぼ 等しいためである。C 2 が環境に依存する㳬数であり，希 硫酸環境の $C_{2}$ が海水環境のそれより小さいことは, 希硫 酸環境のき裂発生寿命が海水環境より知㚘命であることを 示す。したがって，河環境の $\Delta K / N_{c}$ 線戍は，応力集中係 数ごとに希硫酸環境が短寿命となる半行な值線関係とな る。この関係は， $S_{e q} / N_{c}$ 線図の公配が衰寿命側で試験環 境毎に異なるのと対照的である。上記の結果，（8）式の $C_{c} / K_{t}$ 関係は，Kt $K_{t}$ から $(7)$ 式の)基本 $\Delta K / N_{c}$ 線四が推定で きることを示している。

次に, 下限界简食披学強度 $\Delta K_{C F}$ の 玤命 $L_{C F}$ について 検討する。 $f\left(R_{c}, y\right)$ を，腐食速度 $R c$ による $y$ 年後の断面 隇少を示す腐食壾耗率とし，この断面減少がそのまま負葆

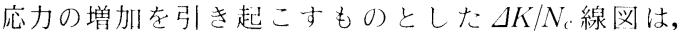
Fig. 19 と Fig. 200破線で表される。Fig. 19 は希硫酸 $\mathrm{pH} 4$ 環境の $R_{c}=0.2 \mathrm{~mm} /$ year に対する $\Delta K / N_{c}$ 関係であ り, Fig. 20 は希硫酸 pII 2 環境の $R_{c}=5.5 \mathrm{~mm} /$ year に対 する $\Delta K / N_{c}$ 関係である。本切欠き武験片の場命，希硫酸 $\mathrm{pH} 4$ 環境に打ける $\Delta K_{C F}$ のき裂発生㚘命は， $K_{t}=3.77$ が $N_{c}=5.57 \times 10^{6}, K_{t}=1.2$ が $2.46 \times 10^{\top}$ となり，これらに対 する $L_{\text {CF }}$ は扩よそ 1.1 4.7 年之なる。间様に, 希硫酸 $\mathrm{pH} 2$ 環境に扔ける $\Delta K_{C F}$ け $N_{c}$ は， $K_{\text {I }}=3.77$ が $8.4 \times 10^{5}$, $K_{t}=1.2$ が $2.0 \times 10^{6}$ であり，L（Fはそれぞれほぼ 2 ケ月よ び4.6ヶ月となる。

本来, 希硫酸 $\mathrm{pH} 4$ 打よび $\mathrm{pH} 2$ 㻴境の武験は，ばら積 石炭船倉の钼しい腐食環境を模擬している。4.1.2 项で述
ベたように，ばら積石炭船倉が $\mathrm{pH} 2.5$ 程度となる腐食環 境にあるとすれば，本実験の希硫酸環境の腐食衰耗を考慮 した腐食疲労の目安は，ほぼ得られたものと判断する。

\section{5. 結 論}

ばら積石炭船倉の腐食と腐食疲労に関し，石炭滲出液の 分析，希硫酸環境における浸漬試験，き裂進展試験および 腐食疲労試験を行い, 海水環境の結果と合わせて検討し た。これらの試験から，以下の結論が得られた。

（1）石炭から 120 時間以内に滲出される液は，酸性濃 度が時間とともに増加し, $\mathrm{pH} 2.5$ 程度に低下する。この 酸性は，石炭中の硫酸鉄によるものである可能性が高い。 石炭を 200 時間以上浸漬して滲出される液は，ほぼ中性の 溶液となる。

（2）石炭からの酸性滲出液の腐食速度は，希硫酸環境 の腐食試験で模擬できる。浸漬 2,000 時間における腐食速 度 $R_{c}(\mathrm{~mm} /$ year $)$ と $\mathrm{pH}$ の関係は，次式で表される。

$\log R_{c}=-1.19+7.81 /[\mathrm{pH}]^{2}$

（3）希硫酸環境の疲労強度 $S_{e q} / N_{c}$ 線図は，平滑試験 片の最大応力が下降伏点相当の等価応力 $L_{l y}$ を境に折れ 曲がる。 $S_{e q}>L_{l y}$ の勾配は，大気中，海水中および溶接 基礎継手と変わらないが， $S_{e q}<L_{\iota y}$ の勾配は海水環境よ り大きくなる。希硫酸環境の疲労き裂発生機構は, 海水環 境と基本的に変わらないが，腐食溶解速度が大きいことが 腐食ピットの成長と疲労き裂発生に影響を及ほしている。

（4）希硫酸 $\mathrm{pH} 4$ および $\mathrm{pH} 3$ 環境のき裂進展特性は, 海水環境 $\mathrm{pH} 8.2$ とほとんど変わらない。

（5）希硫酸 $\mathrm{pH} 4$ および $\mathrm{pH} 2$ 環境において, 腐食ピ ットから疲労き裂が発生する条件 $\Delta K_{C F}$ はそれぞれ 3.60 拀よび $5.39 \mathrm{MPa} \cdot \mathrm{m}^{1 / 2}$ であり，腐食溶解が支配的となる き裂進展速度はそれぞれ $5.63 \times 10^{-10}$ および $1.90 \times 10^{-9} \mathrm{~m} /$ cycle と推定される。

（6）き裂進展特性から得られる基本 $\Delta K / N_{c}$ 線図 $\Delta K$ $=C_{c} N_{c}{ }^{-1 / m}$ は, 定数 $C_{c}$ が応力集中係数 $K_{t}$ と直線関係 $C_{c}=C_{1} K_{t}+C_{2}$ にある。その勾配 $C_{1}$ は海水環境と希硫酸 環境ともほぼ等しく， $C_{2}$ は希硫酸環境が海水環境より小 さい。

（7）腐食疲労強度の下限值 $\Delta K_{C F}$ に対する寿命は，本 供試材の切欠き試験片に適用すると, 希硫酸 $\mathrm{pH} 4$ 環境が $1.1 \sim 4.7$ 年, $\mathrm{pH} 2$ 環境が 2 4.6 ケ月である。これらの 期間に達すると, 疲労き裂の発生より腐食衰耗が支配的と なる。

\section{参 考 文 献}

1）水上知夫・石川一郎：最近の船体損傷の傾向と刘 策, 日本海事協会会誌, No. 227, 1994（II）,pp. 115131.

2）検查技術部：高歯大型ばら積貨物船に関する調査一 高粭大型ばら積貨物船調查会報告から一，日本海事 
協会会誌, No. 219, 1992 (II), pp. 79-117.

3）小林佑規・田中義久・後藤英信・松岡一祥・本橋嘉 信：造船用鋼板切欠き材の腐食疲労強度, 日本造船 学会論文集, 第 182 号, 平成 9 年, pp. 751-761.

4）小林佑規 - 田中義久 - 後藤英信 - 松岡一祥 - 本橋嘉 信：人工海水中における造船用鋼板の長寿命腐食疲 労強度の検討, 日本造船学会論文集, 第 183 号, 平成 10 年, pp. 383-390.

5）小林佑規 - 田中義久 - 後藤英信 - 松岡一祥 - 本橋嘉 信: 造船用鋼突合せ溶接継手の人工海水中疲労強 度, 溶接学会論文集, 第 16 巻, 第 3 号, 1998, pp. 382387.

6) K. MATSUOKA and Y. KOBAYASHI : Influence of Maximum Stress of Fatigue Crack Initiation Life of Welded Steel Joints and Notched Steel Plates, IIW Document XIII-1711-98.

7）駒井謙治郎・箕島弘二・木下定・金貴植：人工海水 中に打ける高張力鋼の腐食疲労き裂発生, 日本機械 学会論文集 (A 編), 第 53 巻, 第 496 号, 昭和 62-12, pp. 2267-2273.

8）村上敬宣・鶴秀登・坂本幸治：応力集中部における 微小表面き裂の応力拡大係数, 材料, Vol. 35, No. 396, 1986, pp. 998-1003.

9）松岡一祥・藤井英輔：鋼溶接継手の疲労き裂発生寿 命の一評価法, 日本造船学会論文集, Vol. 178, Dec.
1995, pp. $513-522$.

10）遠藤吉郎・駒井謙次郎共著：金属の腐食疲労と強度 設計, 養賢堂, 第 1 版, 1982, p. 22.

11) K. Endo, K. Komai and T. Shikida: Crack growth by Stress-Assisted Dissolution and Threshold Characteristics in Corrosion Fatigue of a Steel, Corrosion Fatigue, ASTM STP 801, pp. 81-95.

12）駒井謙治郎・箕島弘二・金貴植：長時間腐食疲労き 裂進展特性推定法に関する一提案, 日本機械学会論 文集 A，第 54 巻, 第 499 号, 1988, pp. 509-512.

13) R. Akid and K. J. Miller: Short Fatigue Crack Growth Rate Behaviour of a Low Carbon Steel under Corrosion Fatigue Conditions, Fatigue Fracture Engineering Material Structure, Vol. 14, No. 6, 1991, pp. 637-649.

14）遠藤吉郎・駒井謙治郎・木下定：長寿命域ならびに 乾湿繰返しにおける腐食疲労強度，材料，Vol. 25, No. 276, 1976, pp. 894-898.

15）中島正貴・加藤容三：腐食環境中における高強度鋼 の微小き裂進展挙動に及ぼす繰返し速度の影響, 日 本機械学会論文集 A, 第 54 巻, 第 504 号, 1988, pp. 1467-1473.

16）西谷弘信・陳玳珩・才本明秀：体積力法による二次 元忍力解析汎用プログラム, 培風館, 初版, 1994. 